\title{
熟練操縦者の制御戦略を考慮した旋回クレーンの制御†
}

\author{
大 音 光 博*. 安 信 誠 二**
}

\section{A Rotary Crane Control Method Based on a Skillful Operator's Knowledge}

\author{
Mitsuhiro OHTO* and Seiji YasunobU**
}

\begin{abstract}
A crane active on the construction site is the loading machine that transports load to a fixed position by doing the turn movement centering on a part of the boom. The fulcrum of the rope draws circular arc tracks in such turn cranes and the behavior of load is very complex. Therefor the operations that maintain sway of a turn crane depend on an operator's skill. We propose anti-sway control method of the rotary crane based on a skillful operator's knowledge. The computer simulation and experiment of the loading control were executed by using this method. It was confirmed that the proposed method is effective.
\end{abstract}

Key Words: rotary crane, operator's skill, anti-sway control

\section{1.はじめに}

建設現場等で活躍するクレーン車等は,ブームの一端を中 心に旋回運動を行うことにより荷物を所定の位置まで運搬す る荷役機械である。このような旋回クレーンにおいては, 所 定位置までの運搬時間短縮が重要な課題の一つである。この クレーンでは，ブームが旋回運動を行うことから，ロープ支 点は円弧状の軌跡を描くため, 吊り荷の摇れは, 遠心力の影 響を考慮した円錐振子としてモデリングする必要がある ${ }^{1)}$. また，吊り荷の支点の運動自体もクレーン本体のダイナミク スの影響を受けるために, 複合動作時の吊り荷の挙動はいっ そう複雑化することになる。つまり，ブームの位置（旋回角 度）と吊り荷の摇れの両方を同時に制御しなければならない ことは，天井走行クレーン 2) 6)などと同様であるが，更に， 吊り荷の振れは二次元的な振れである円錐振子であることか ら，その抑制はよりいっそう困難である。このような残留振 れの抑制は团難であったため, 熟練操縦者の技術に頼る度合 いが大きく7),8)，非熟練者でも簡単に扱えるシステムが望ま れており，自動化に向けた研究が進められている99,10).

そこで，本論文では，熟練操縦者が旋回動作のみによって， 残留振れを抑えた上手い制御を行っていることにに注目して，

†第 23 回知能システムシンポジウムで発表 (1996.3)

* 筑波大学大学院理工学研究科 つくば市天王台 1-1-1 現在, いすが自動車 (株)

** 筑波大学構造工学系 つくば市天王台 1-1-1

* Master's Program in Science and Engineering, University of Tsukuba, Tsukuba Now, ISUZU MOTORS LIMITED

** Institute of Engineering Mechanics, University of Tsukuba, Tsukuba (Received March 29, 1996) (Revised November 5, 1996)
その制御戦略を解析し, 残留振れが円錐振子の形態をとる旋 回クレーンの特性を充分考慮することによって，旋回動作の みにより，精度よく停止し，残留振れを抑制できる制御方式 を構築した ${ }^{11)}$. 更に, 計算機シミュレーションと模型実験に より，その有効性を検証する。

\section{2. 旋回クレーンのダイナミクス}

\section{1 旋回クレーンのモデリング}

本研究の制御対象である旋回動作を有するクレーンの振り 子系は, 旋回時（荷役作業時）における吊り荷支点の運動が 直線上の軌道となる天井走行クレーンやコンテナ・クレーン などとは異なる。このクレーンは旋回時における吊り荷の支 点の運動が円弧状の軌道となるため, 遠心力の影響を考慮し て，吊り荷の振れを円錐振子として，モデリングする必要が ある。

ここでは，運動方程式の導出および制御問題としての定式 化を行うため簡略化した数学モデル ${ }^{12)}$ を用いる. クレーン 本体（ブーム）およびロープを剛体とし，吊り荷を質点とし て取り扱う。また，ロープとその下端のフック等の重量も無 視する．これにより，旋回クレーンはFig.1 のようなモデル で表される。用いた記号を Table 1 に示す.

ここで， $\alpha$ は X-Y 平面への吊り荷支点の投影点 $\mathrm{O}^{\prime}$ と吊り 荷の投影点 A を結ぶ線分 O'A とブームの投影線 OO'のなす 角（吊り荷の進み角）であり， $\beta$ はロープと垂直線のなす角 （吊り荷の振り上がり角）である.

\section{2 運動方程式の導出}

質点に働く力の各成分は, 重力加速度を $g$ とすると,

$$
\begin{aligned}
& m \ddot{x}=-f \cdot \sin \beta \cdot \cos (\theta+\alpha) \\
& m \ddot{y}=-f \cdot \sin \beta \cdot \sin (\theta+\alpha)
\end{aligned}
$$




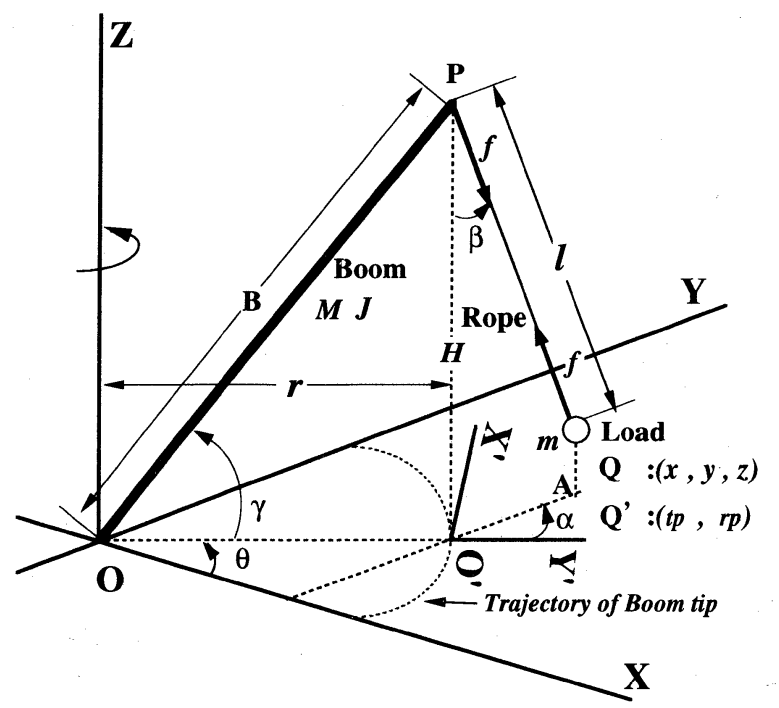

Fig. 1 Rotary crane system model

Table 1 Parameter in model

\begin{tabular}{|c|c|}
\hline $\mathrm{O}$ & center of rotating \\
\hline $\mathrm{P}$ & rope fulcrum \\
\hline A & projection point of load to X-Yplane \\
\hline $\mathrm{Q}$ & coodinates of load in base coodinate system \\
\hline$Q^{\prime}$ & coodinates of load in O'coodinate system \\
\hline$l$ & rope length \\
\hline$r$ & rotating radius of boom \\
\hline B & boom length \\
\hline$m$ & mass of load \\
\hline$M$ & mass of boom \\
\hline$J$ & inertia moment of boom \\
\hline$\theta$ & rotating angle of boom \\
\hline$\gamma$ & undulation angle of boom \\
\hline$\alpha$ & rotating angle of load \\
\hline$\beta$ & swing up angle of load \\
\hline$f$ & tention in rope \\
\hline$H$ & height of rope fulcrum \\
\hline
\end{tabular}

$m \ddot{z}=-m g+f \cdot \cos \beta$

また，各座標と角度の間には次の関係がある。

$$
\begin{aligned}
& x=r \cdot \cos \theta+l \cdot \sin \beta \cos (\theta+\alpha) \\
& y=r \cdot \sin \theta+l \cdot \sin \beta \sin (\theta+\alpha) \\
& z=H-r \cdot \cos \beta
\end{aligned}
$$

今, 振れが小さく $\beta$ が小角, すなわち, $\beta \ll 1, \cos \beta \simeq 1$ と線形近似すると, 旋回動作においては, $H, l$ が一定であ るので, 式 (6) から $\ddot{z} \simeq 0$, 従って, 式 (3) より, $f \simeq m g$, となる。市に，式 (1), (2), (4), (5) から次式が求まる.

$$
\begin{aligned}
& \ddot{x}=-\left(\frac{g}{l}\right)(x-r \cdot \cos \theta) \\
& \ddot{y}=-\left(\frac{g}{l}\right)(y-r \cdot \sin \theta) \\
& \ddot{\theta}=K u
\end{aligned}
$$

ここで，Kはブームの質量 $M$ と慣性モーメント $J$ を含む定 数, $u$ は操作量である.

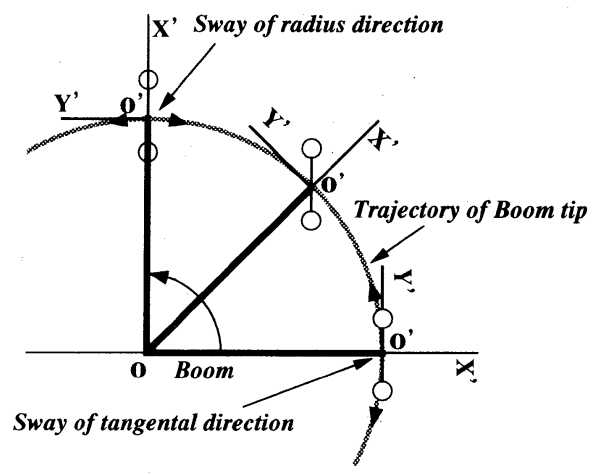

Fig. 2 Transition of load sway

上式が，旋回クレーンの吊り荷の運動（式 (7), (8) ) と 旋回動作（式 (9) ) を記述する連動方程式である。吊り荷 の運動は $\mathrm{A}$ 点の運動に代表され，操縦者から見た吊り荷の 運動は O'座標系において考えた方が直感的にわかりやすい. そのため, 以後, O’座標系に抒ける $\mathrm{A}$ 点の運動に注目する. O'座標系での吊り荷の座標 $(t p, r p)$ は,

$$
\begin{aligned}
t p=-(x-r & \cdot \cos \theta) \cdot \sin \theta \\
& +(y-r \cdot \sin \theta) \cdot \cos \theta \\
r p=(x-r & \cdot \cos \theta) \cdot \cos \theta \\
& +(y-r \cdot \sin \theta) \cdot \sin \theta
\end{aligned}
$$

となる。

\section{3 旋回クレーンの特性}

天井走行クレーンなどは，ロープ支点が直線軌道を描くた め, 吊り荷の振れは 1 次元の振れとなり, ロープ支点の進行 方向と吊り荷の振れの方向が常に一致している。しかし，旋 回クレーンの場合, ブームが旋回動作を行うためロープの支 点が円弧状の軌跡を描く. 従って，ロープ支点の進行方向と 吊り荷の振れの方向が，旋回角度に応じてずれるという特 性を持つ。例えば，ブームを $90 \mathrm{deg}$ 旋回させる場合，初期 位置においてブームの加速によって発生する旋回方向の振れ は，最終到達位置における半径方向の振れとなる。ここで, ロープ支点の描く軌跡を基準円と呼ぶことにすると，旋回方 向とは基準円の接線方向，同じく半径方向とは基準円の法線 方向のことを指す。この時の吊り荷の振れが推移する様子を

Fig. 2 に示す.

また，半径方向の振れに注目すると，旋回時には吊り荷に 働く遠心力により，その振れの中心が基準円より外側に移動 する.その振れの様子を Fig. 3 に示す.

このような特徴を持つ振れにどのように対応するかが旋回 クレーン特有の問題である.

\section{3. 制御方法の構築}

旋回クレーンにおいて，起伏角を一定とし，旋回方向の操 作のみを行う場合には，残留振れの旋回方向に対する振れに 関しては，その振れの方向がブームの動作方向（ロープ支点 


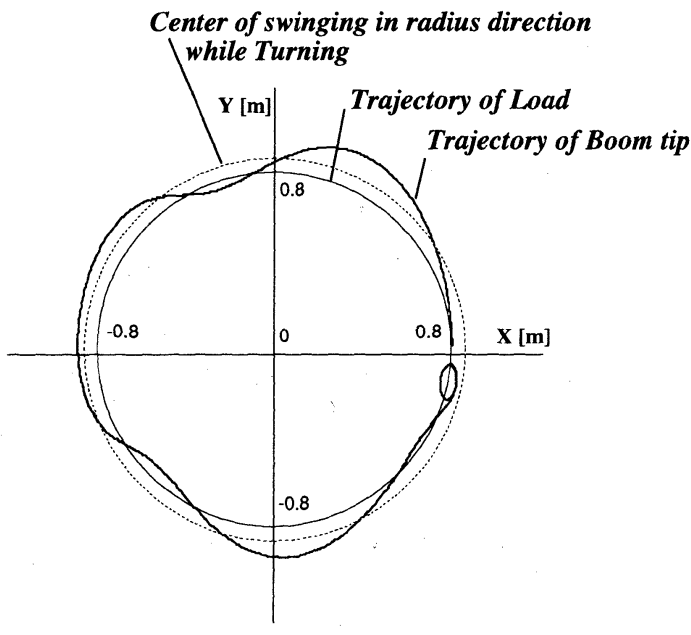

Fig. 3 Characterristic of load sway

の進行方向）と局所的に一致するため，ブームの旋回動作に よってアクティブな制御を施し，その振れを抑え込むことが 可能である. 一方, 残留振れの半径方向に対する振れに関し ては，その振れの方向がブームの動作方向と一致しないため, アクティブに対応することができない．しかし，熟練操縦者 は旋回動作のみによっても，旋回方向；半径方向の両方向に 対する残留振れの少ない上手な運転（制御）を行っている. ここでは，この点に着目し旋回動作のみによって残留振れを 抑制した旋回クレーンの制御，すなわち，1つのアクチユエー 夕によって，旋回方向，半径方向の 2 次元の残留振れを抑制 する制御について検討を行う。

\section{1 熟練操縦者の制御戦略}

熟練操縦者の制御戦略を解析する。旋回クレーンはその構 造上, 吊り荷の振れの旋回方向成分と半径方向成分が旋回角 度に応じて入れ替わったり，旋回中には遠心力により，半径 方向の振れの中心が基準円より外側に移動するといった特徴 を持つ. また, その振り子系はロープ長に応じた固有周期を 持つ. 熟練操縦者が残留振れの少ない上手な運転を行うこと ができるのは，このような旋回クレーン特有の性質を経験的 に知っており，それを積極的に利用していると考えることが できる。つまり，熟練操縦者は，ブームの旋回時において， 吊り荷に働く遠心力により外側にずれた半径方向の振れの中 心をタイミングよく減速することにより元に戻し，本来なら ば，ブームの起伏動作や，伸縮動作によって抑え込む半径方 向の振れを旋回動作のみによって抑制している。

すなわち, 熟練操縦者の操作は, 旋回動作を加速領域, 定 速領域, 減速領域の 3 つの領域に分割し, 定速領域では意図 的にある程度の振れを発生させるように加速し，半径方向の 振れの様子を観察しながら, 吊り荷が基準円上に戻ってくる タイミングを見計らって減速の動作を行う制御戦略に基づい ている.

\section{2 制御則の定式化}

熟練操縦者の操作を定式化するために, Fig. 4 に示す, ブー

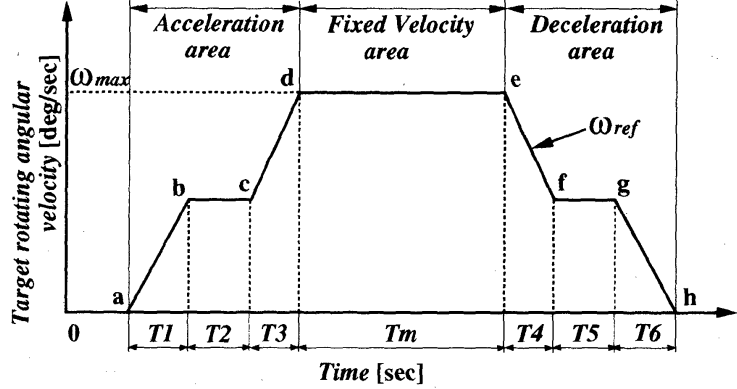

Fig. 4 Modes of the trabersing interval

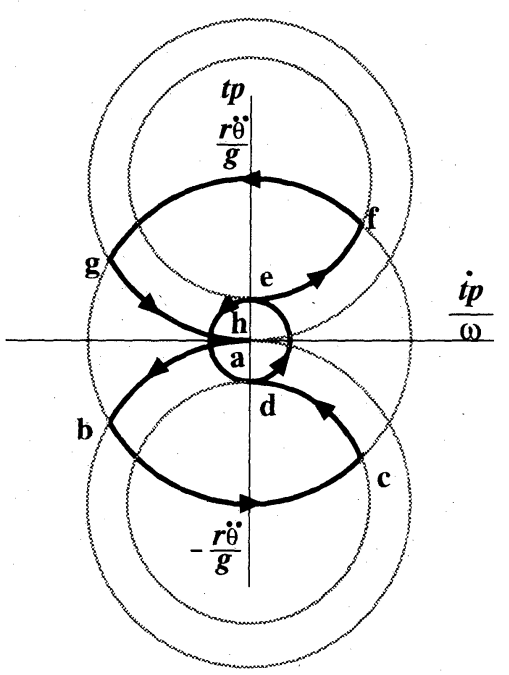

Fig. 5 One example of a time trajectory of tangental directoin

ムの旋回角速度パターンを作製した．図中の $\mathbf{a} \sim \mathbf{d}$ が加速領 域， $\mathbf{d} \sim \mathbf{e}$ が定速領域，eｈ が減速領域である.

ここで, Fig. 4 から吊り荷の振れの特徵をよく表す位相平 面図に移行し，具体的な設計を行う，旋回方向に対する振れ に関しては，天井走行クレーンなどの振れ止め制御が応用で きる。そこに，半径方向に対する振れをも同時に抑制する夕 イミングを付加した旋回角速度パターンを生成する。

旋回クレーンの場合，ブームの先端の加速度が $r \ddot{\theta}$ となる。 吊り荷の振れの旋回方向に対する振れの位相平面上での軌 跡を描いたものを Fig. 5 に示す. 加速時 $(\mathbf{a} \sim \mathbf{b}, \mathbf{c} \sim \mathbf{d})$ に は $(0,-r \ddot{\theta} / g)$, 減速時 $(\mathbf{e} \sim \mathbf{f}, \mathbf{g} \sim \mathbf{h})$ には $(0, r \ddot{\theta} / g)$, 定速時 $(\mathbf{b} \sim \mathbf{c}, \mathbf{d} \sim \mathbf{e}, \mathbf{f} \sim \mathbf{g})$ には原点を中心とした円を描く。ま た，描く円の中心が切り換わる際に，吊り荷の振れ角（量） $t p$ と振れ角速度 $\dot{t} p$ は連続でなければならないので，相軌跡 はそれぞれの円弧をつなぎ合わせたものとなる。軌跡が円 を描くのに要する時間は吊り荷による振り子系の固有周期 $T=2 \pi \sqrt{l / g}$ に等しく, 軌跡は左回りに移動する。

ここで，目標旋回角度を $\theta_{T}$ とし，熟練者の操作の一例と して， $T_{1}$ から $T_{6}$ の各区間時間を以下のように決定する。

$$
T_{1}=T_{6}=\frac{T}{6}
$$




$$
\begin{aligned}
& T_{2}=T_{5}=\frac{T}{3}-T_{\alpha} \\
& T_{3}=T_{4}=\frac{T}{6} \\
& T_{m}=\left(n+\frac{\pi+\theta_{T}}{2 \pi}\right) T
\end{aligned}
$$

$n$ はゼロ以上の整数

式 (13)の $T_{\alpha}$ により加速領域終了後に意図的に残す振れの 量を調節する. $T_{\alpha}$ を大きくすると Fig. 5 の中心部分に現れて いる定速領域中の振れが大きくなり，逆に小さくすると振れ が小さくなる．この $T_{\alpha}$ の值は, 一定速度で旋回中に半径方向 の振れと旋回方向の振れがほほ同じとなるように位相面図よ り設定する．この定速領域に意図的に残す振れが，本論文で 取り込んだ制御戦略の特徴を最も良く示す部分である。また， この場合, 加速領域, 減速領域はそれぞれ $\left((2 / 3) T-T_{\alpha}\right)$ の 時間を要する。これより，目標位置に精度よく停止するため に，目標角度を考虑した式 (15) で定速領域の時間を算出す る. 式 (15) は, 吊り荷の固有周期に依存しており, ゼロ以

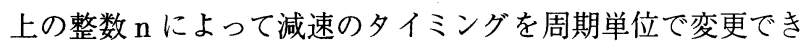
る。一般には, 最大旋回角速度がクレーンの性能から決まる 速度を超えない範囲で最小の $\mathrm{n}$ をえ，旋回時間を最小にす る. 次に, 平均角速度を $\omega_{a v}$, 最大角速度を $\omega_{m a x}$, 角加速 度を $a c c$ とすると，それぞれ以下のように求めらる。

$$
\begin{aligned}
\omega_{a v} & =\frac{\theta_{T}}{T_{m}+2\left(T_{1}+T_{2}+T_{3}\right)} \\
\omega_{m a x} & =\frac{T_{m}+2\left(T_{1}+T_{2}+T_{3}\right)}{T_{m}+T_{1}+T_{2}+T_{3}} \omega_{a v} \\
a c c & =\frac{\omega_{\max }}{T_{1}+T_{3}}
\end{aligned}
$$

これにより, 目標旋回角度 $\theta_{T}$ を与えると, それに対応し た, 定速領域の時間 $T_{m}$, ブームの角加速度 $a c c$, 最大旋回 角速度 $\omega_{\max }$, 平均旋回角速度 $\omega_{a v}$ が算出され, 熟練操縦者 の制御戦略を反映したブームの旋回角速度パターンが求まる.

\section{4. 構築した制御法の評価}

前章で構築した制御方法を用いて計算機によるシミュレー ションと模型クレーンを用いた実験を行い，その有効性を検 証する。

\section{1 計算機シミュレーションによる検証}

ここで, ブームは速度フィードバック制御を行うが, 減速 のタイミングをはじめとする，旋回角速度パターンは吊り荷 の固有周期に依存しており，パターンからのわずかな追従遅 れが，制御結果に大きく影響を与える。よって，フィードバッ クゲインは大きめに設定し，追従性をよくした状態でシミュ レーションを行った.

\subsection{1 シミュレーション結果}

任意の目標旋回角度に対して制御が可能であるが，ここで は, 目標旋回角度が $90[\mathrm{deg}]$ の場合についてシミュレーション
Table 2 Parameters in target angular velocity

\begin{tabular}{ccc}
\hline \hline$T_{1}=T_{6}$ & $=0.2365$ & {$[\mathrm{sec}]$} \\
$T_{2}=T_{5}$ & $=0.4431$ & {$[\mathrm{sec}]$} \\
$T_{3}=T_{4}$ & $=0.2365$ & {$[\mathrm{sec}]$} \\
$T_{m}$ & $=3.9029$ & {$[\mathrm{sec}]$} \\
\hline$\omega_{a v}$ & $=15.6929$ & {$[\mathrm{deg} / \mathrm{sec}]$} \\
$\omega_{\text {max }}$ & $=18.6476$ & {$[\mathrm{deg} / \mathrm{sec}]$} \\
acc & $=39.4778$ & {$\left[\mathrm{deg} / \mathrm{sec}^{2}\right]$} \\
\hline \hline
\end{tabular}

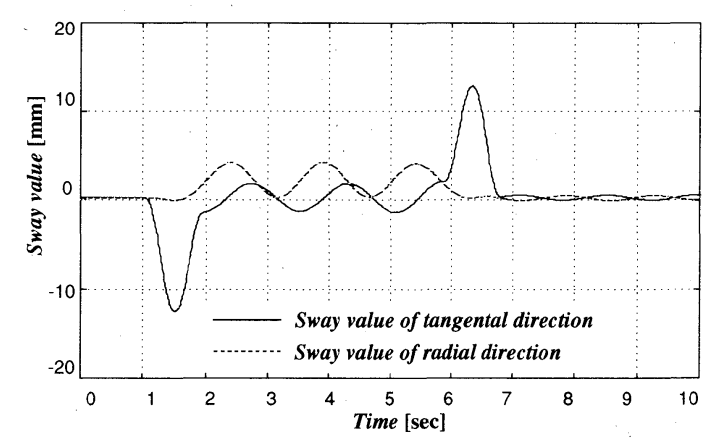

Fig. 6 Response of load sway

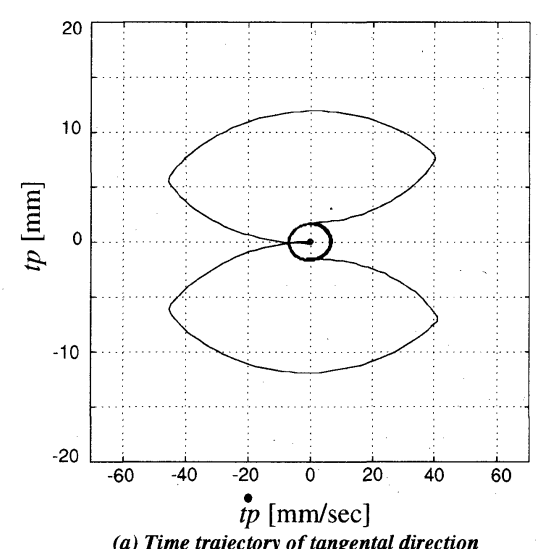

(a) Time trajectory of tangental direction

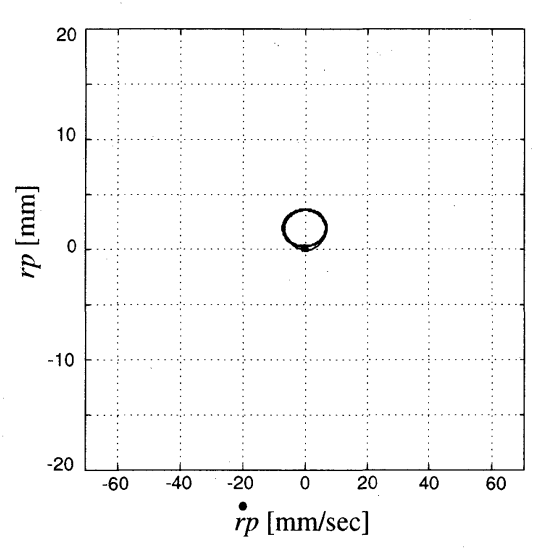

(b) Time trajectory of radius direction

Fig. 7 Tine trajectory of the rope system

結果を示す.ブームの最大旋回角速度が $20[\mathrm{deg} / \mathrm{sec}]$ 程度に なるように，式 (15) 中でパラメータ $n=2$ とした，目標旋回 角速度パターンを形成する各パラメータを Table 2 に示す. 旋回方向と半径方向の吊り荷の振れの時間応答を Fig. 6 に, 

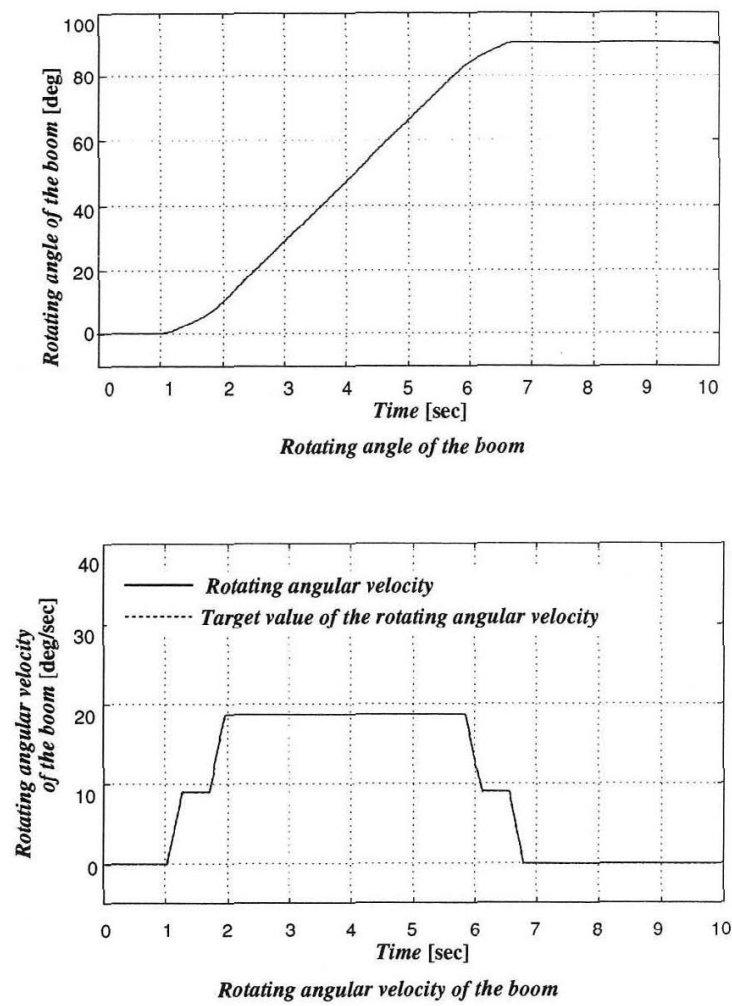

Fig. 8 Response of boom rotating

吊り荷の振れの旋回方向成分の位相平面上の軌跡を Fig. 7(a) に同じく半径方向成分の位相面上の軌跡を Fig. 7(b) に, ブー 么の旋回の時間応答を Fig. 8 にそれぞれ示す.

\subsection{2 シミュレーションの考察}

ここで，目標旋回角度に対して，半径方向の振れに注目す ると, 吊り荷の振れの時間応答（Fig. 6)，あるいは位相平 面軌跡（Fig.7(b)）より，定速旋回中には遠心力と式 (13) で設定した $T_{\alpha}$ の効果により，振れの中心が外側（正の方向） にずれていることが確認でき，旋回動作のみでも， タイミン グ良く減速を行うことで，ずれた振れの中心を基準円上（ゼ 口）に戻し，旋回方向，半径方向共に残留振れを抑制した制 御を実現できることを確認した．荷役作業終了後における若 干の残留振れは，システムの非線形性によるものと推測され る。また，ブームの旋回角度の時間応答（Fig. 8)より，目 標旋回角度に精度良く停止していることが確認できる。また， 異なる目標旋回角度に対しても同様の結果が得られている。 これらのことから, 本研究において構築した制御方法の有効 性を確認した。

\section{2 模型実験による検証}

次に，模型クレーンによる実験を行い，構築した制御方法 の実機での有効性を検証する.

\subsection{1 模型クレーン}

作製した模型クレーンの概観を Photo. 1 に，構成を Fig.9 に，その仕様を Table 3 に示す.

この模型クレーンは, ブームの旋回動作, 若干のロープの 巻き上げ，巻き下げ，電磁石による荷物（鉄球）の脱着が可

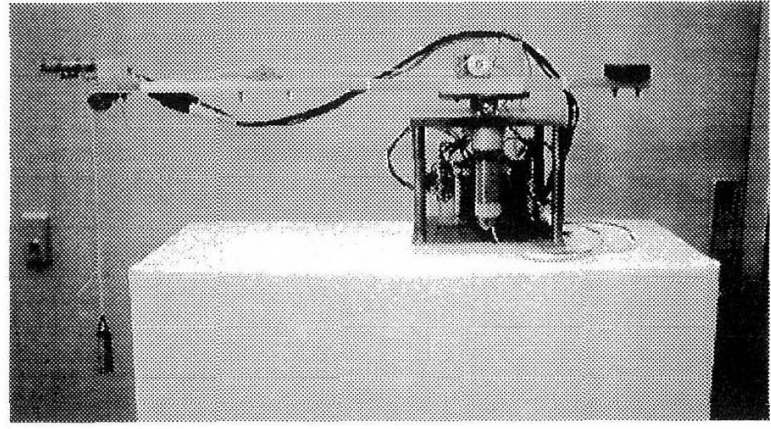

Photo. 1 A rotating crane used in experiments

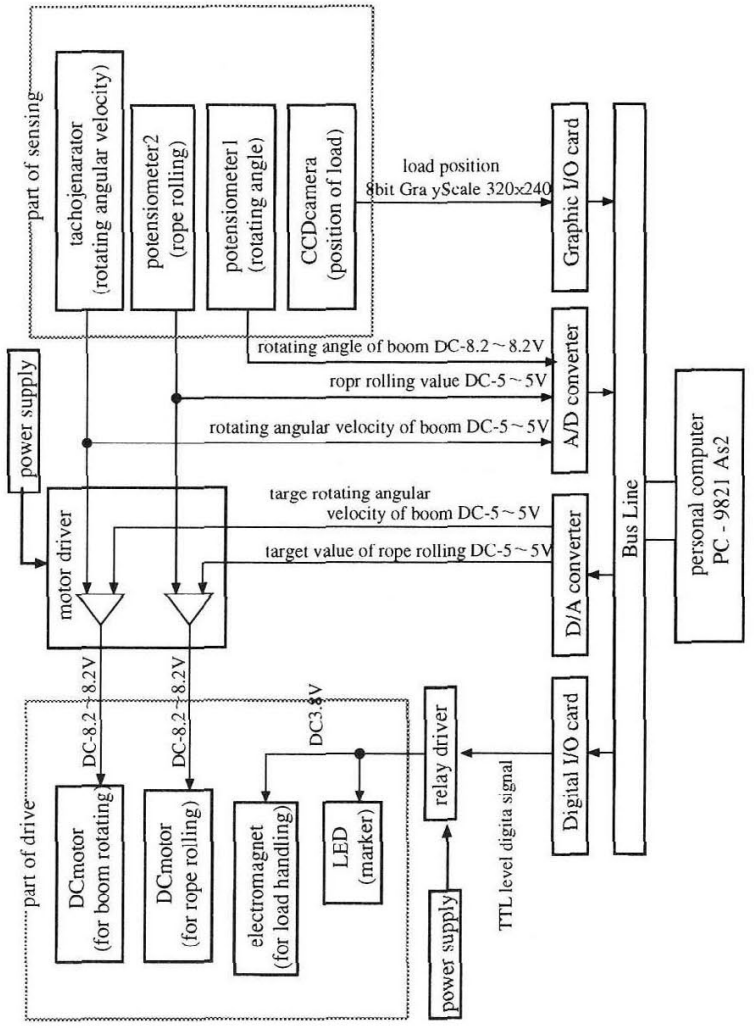

Fig. 9 Outline chart in experiment device

Table 3 Parameter of the rotary crane

\begin{tabular}{clll}
\hline \hline$m$ & $:$ & 0.05 & {$[\mathrm{~kg}]$} \\
$M$ & $:$ & 0.5 & {$[\mathrm{~kg}]$} \\
$\mathrm{B}$ & $\vdots$ & 0.5 & {$[\mathrm{~m}]$} \\
$l$ & $:$ & 0.5 & {$[\mathrm{~m}]$} \\
$r$ & $:$ & 0.35 & {$[\mathrm{~m}]$} \\
$K$ & $:$ & 0.585 & {$[\mathrm{Nm} / \mathrm{A}]$} \\
\hline \hline
\end{tabular}

能となっている．また，ブーム旋回軸上のポテンショメータ からブーム旋回角度を, 旋回用モータ軸上の DC タコジェネ レータからブーム旋回角速度を, ブームの先端に取り付けた CCD ボードカメラから吊り荷の位置をそれぞれ検出するす ることができる。

ブームの旋回動作は，DC タコジェネレータで検出された速 度信号と目標速度指令をモータドライバに入力し, 速度フィー ドバック制御を行う。目標速度指令は，ディジタルーアナログ 


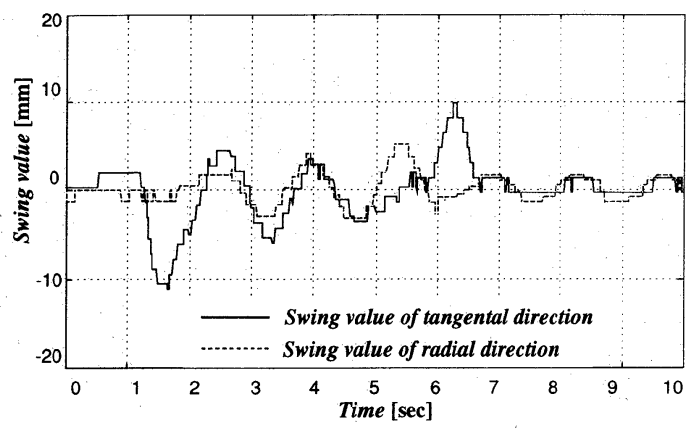

Fig. 10 Response of load sway

コンバータを介したコンピュータから電圧值 $(-5 \sim+5 \mathrm{~V})$ と して出力する.

実機におけるクレーンの振れ止め制御では，吊り荷の振れ 角をどのようにして検出するかという課題がある：これまで， ロープの支点にストレインゲージやポテンショメータを取り 付けて，その振れ角を検出する等の手段が用いられてきた. しかし, これらの方法は, ロープ長が長い場合, 微小振れに 対して計測誤差が大きいという久点がある，そこで，ここで は，ブーム先端に CCD カメラを搭載し，ロープ下端の電磁 石に発光ダイオードを取り付け，その光点を検出することで, 吊り荷の位置（振れ角）を測ることにした. CCD カメラから の, 8 bit (256 階調, グレースケール) デー夕, $320 \times 240 \operatorname{dot}$ を画像処理ボードのフレームメモリに取り込み，適当なしき い值を設定しコンピュータで 2 值処理を行う。制御全体とし ての処理速度を向上させるため, 取り込んだデータにおいて， 処理を行うために実際に走査する範囲は, 前サンプリング時

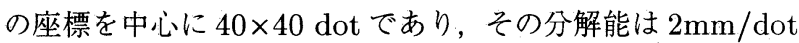

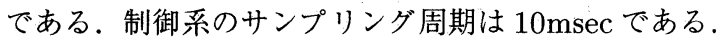

\section{2 .2 実験結果}

シミュレーションと同様に，いくつかの目標旋回角度に対 して実験を行った中で, 目標旋回角度が $90[\mathrm{deg}]$ の場合の結 果について, 吊り荷の振れの時間応答を Fig. 10 に,ブーム の旋回の時間応答を Fig. 11 にそれぞれ示す.

\section{2 .3 実験の考察}

吊り荷の振れの時間応答（Fig. 10）より，旋回動作のみに よって，旋回方向，半径方向共に残留振れを抑制した制御が 実現できた。シミュレーションと比較した場合，残留振れが 若干大きくなっているが，これは，旋回角速度パターンへの 追従のわずかな遅れが，その要因の一つであると考えられる. 更に，今回作製した模型クレーンのブームに剛性がやや不足 していたため，吊り荷の振動により，ブーム自体に，わずか ながらしなりが生じたことも，特に半径方向の残留振れを大 きくした要因の一つではないかと推測される。しかし，残留 振れは $2 \mathrm{~mm}$ 程度であり，鉄球の直径 $20 \mathrm{~mm}$ に比較しても十 分小さく，残留振れはほほ抑えられているといってよい，ま た，ブームの旋回角度の時間応答（Fig. 11）より，目標旋回 角度に精度良く停止していることが確認できる。これらのこ
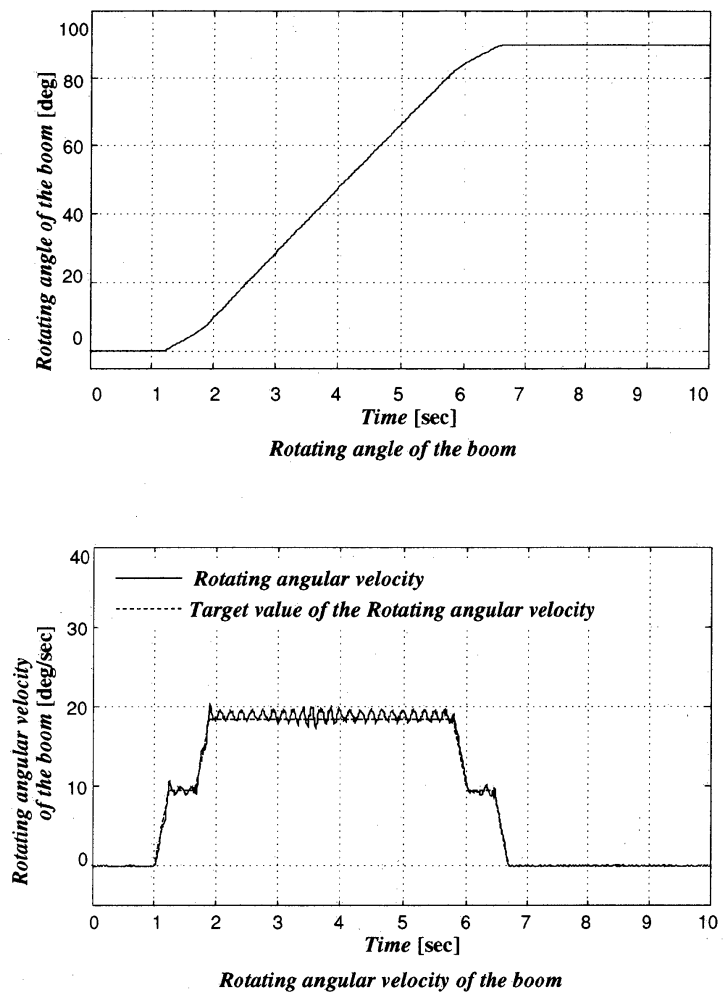

Fig. 11 Response of boom rotating

とから，本研究において構築した制御方法が実機に対しても 有効であることを確認した。

\section{5. おわりに}

本論文では，クレーン車に代表される旋回クレーンを対象 として, 旋回動作のみで残留振れを抑制して, 目標角度まで 荷物を運搬する制御について検討した。

旋回クレーンの吊り荷の振れは円錐振子となるため，本来， ブームの旋回動作だけでは，半径方向に対する振れを押さえ 込むことは困難である。しかし，熟練操縦者による運転では， 旋回動作のみによって，その半径方向の振れも抑えた制御が 成されている。 そこで本研究では，熟練操維者の運転に注目 し，その制御戦略の解析から，ブームの加速終了後に遠心力 による吊り荷の振れを意図的に発生させ，半径方向に対する 振れの中心をロープ支点の描く軌跡である基準円に対して外 側へとずらし，そのずらせた振れの中心が元に戻ってくる夕 イミングを見計らい，ブームを減速することによって，目標 位置での旋回方向，半径方向の両方向に対する残留振れを抑 制した制御方法を構築した。

本制御方法の有効性を評価するために，計算機によるシ ミュレーションを行った結果, 半径方向に対する吊り荷の振 れが遠心力により外側へとずれる様子が表れており，目標位 置で精度良く停止し，かつ残留振れを抑えた旋回制御を実 現することができた，更に，模型クレーンを自作し，実験を 行った結果，シミュレーションと同様に目標位置における停 止精度もよく，旋回方向，半径方向の両方向に対する残留振 
れを抑制した制御を実現することができ，本制御方式が実機 に対しても有効であることを実証した，また，運搬開始時に 初期振れがある場合を考虑した制御方式については, 現在検 討を進めており機会をあらため報告する.

$$
\text { 参考文 献 }
$$

1）田中芳夫，上田哲史，川上博：球面振子を有するクレーンの シミュレーション法, 日本機械学会論文集（C 編）， 59-559, $814 / 818(1993)$

2）井口雅一: クレーンの制御に関する研究, 日本機械学会論文 集 (第 1 部)，39-320，1225/1234(1973)

3）森下蟤：走行クレーン運転自動化のための振れ止め制御, 計 測自動制御学会論文集, 14-6, 739/743(1978)

4）美多勉, 金井隆：トロリーの最大速度に注目したクレーンの最 適運転法, 計測自動制御学会論文集, 15-6, 833/838(1979)

5）進藤祐司, 棌耀明, 坂和愛幸：コンテナ・クレーンの振れ止め 制御, 計測自動制御学会論文集, 19-5，430/432(1983)

6）安信誠二：予見 Fuzzy 制御方式によるコンテナ・クレーン自 動運転, 計測自動制御学会論文集, 22-10, 1066/1073(1986)

7）山田新一, 藤川英司, 森田篤史, 鈴木雄三：旋回クレーンの ファジィ制御, 第 8 回ファジイシステムシンポジウム講演論 文集，45/48(1992)

8）山田新一, 知久豊, 荒井哲三, 藤川英司：ファジィ制御による 旋回クレーンの振れ止めに関する研究, 計測自動制御学会第 34 回学術講演会予稿集, $57 / 58(1995)$

9）井上, 中住, 福島：クレーンの旋回制御シミュレーション, 第 30 回自動制御連合講演会, $65 / 68$ (1987)

10）谷住, 芳村, 日野, 坂井：トラッククレーンの動特性のモデ ル化と制御に関する研究，日本機械学会論文集 (C), 61-582, $549 / 556$ (1995)

11）大音光博, 安信誠二：熟練操縦者の制御戦略に基ついた旋回 クレーンの制御方法の提案”計測自動制御学会第 34 回学術講 演会予稿集, 63/64(1995)

12）土屋輝雄，伊藤公詞：旋回クレーンの荷物の振れ止め制御，計 測と制御， 13-10，797/805(1974)

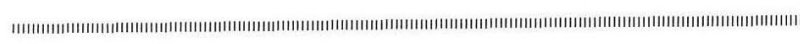

$$
\text { [著者紹介] }
$$

大 音 光 博 (正会員)

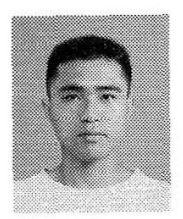
1994 年筑波大学第 3 学群基礎工学類卒業. 1996 年同大学大学院理工学研究科修了. 同年いす心゙自 動車株式会社入社, 現在に至る.

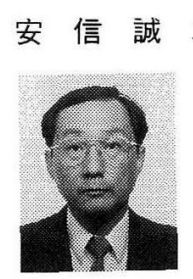

二 (正会員)

1973 年神戸大学工学部計測工学科卒業. 1975 年同大学大学院修士課程修了. 同年 (株) 日立製 作所入社. 1988 年同社システム開発研究所 主任 研究員. 1992 年筑波大学構造工学采助教授, 現在 に至る。昭和 60 年度計測自動制御学会論文賞, 平 成 4 年度 科学技術庁長官賞受賞. 知的制御, ファ ジィ制御, ファジィ情報処理に関する研究に従事. 日本ファジィ学会, 電気学会, IEEEなどの会員. (工学博士)

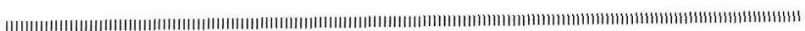

